\title{
The efficiency of using enamel matrix derivative in therapeutic approach of periodontal furcation defects of maxillary and mandibular molars
}

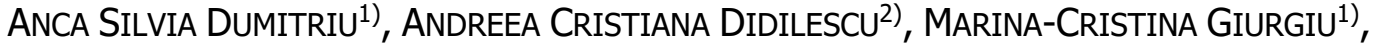 \\ ŞTefan-Dimitrie Albu ${ }^{1}$, CRIStiana Elena PĂdurE ${ }^{1)}$, Ximena AnCA NicolaE ${ }^{1)}$, \\ STANA PĂUNICĂ ${ }^{1)}$
}

1) Department of Periodontology, Carol Davila University of Medicine and Pharmacy, Bucharest, Romania

2) Department of Embryology, Carol Davila University of Medicine and Pharmacy, Bucharest, Romania

\begin{abstract}
Periodontal disease is an inflammatory condition which affects the covering and support structures of the teeth and, if left untreated, leads to tooth loss. Resorption of the alveolar bone from bi- and trifurcation regions of a multirooted tooth due to the progression of a periodontal disease bears involvement furcation. The degree of furcation involvement is clinically assessed by changes in the vertical and horizontal plane at the root separation area. In the approach of the furcation treatment, the morphological and functional particularities of pluriradicular teeth must be considered and the current techniques look for solutions for the regeneration of the destroyed periodontal tissues. Enamel matrix derivative (EMD) has the role of stimulating healing processes through effects on various growth factors, cement formation, angiogenesis and are used single or in combination with bone graft substitute (BGS) or guided tissue regeneration (GTR) in the complex treatment of periodontal disease. The present study follows PubMed publications on the efficiency of EMD in the treatment of pluriradicular tooth furcations. The findings are that there are not many studies in the usage of EMD associated with the treatment of furcations, but it is an important choice in the complex treatment of destructive periodontal disease, and further studies are needed to be done in periodontal regeneration.
\end{abstract}

Keywords: periodontal disease, furcation defects, periodontal regeneration, enamel matrix derivative.

\section{ㅁ Introduction}

Periodontal disease is considered the sixth most prevalent disease in the world, with an unchanged value in the last 25 years according to a Report published by The Economist Intelligence Unit in June 2021 [1]. It is a part of public health interest, related to systemic diseases such as diabetes or cardiovascular disease, and which, untreated, is one of the leading causes of tooth loss.

The destruction of the bone support which holds up the teeth is the result of the inflammatory action generated by the presence of periodontal pathogenic bacteria in the dental plaque. In the lateral maxillary and mandibular areas, which are areas of maximum masticatory stress, the presence of the pluriradicular teeth not only increases the value of implantation, but also creates favorable conditions for the development of dental plaque. The morphological and topographic complexity of the root separation area of the molars and upper first premolars make these areas difficult for instrumentation, especially when periodontal pockets appear through the resorption of interradicular septa [2].

The term of 'furcation involvement' is used to describe the resorption of the alveolar bone into the bi- and trifurcation area of a multirooted tooth due to progression of periodontal disease, as described by the American Academy of Periodontology [3].

The degree of furcation involvement is clinically assessed by changes in vertical and horizontal plane at the root separation area, more easily accessible to the mandibular molars, but more difficult to access from the approximal side at the level of the maxillary teeth, so it is important to correlate with the radiological aspect, even cone-beam computed tomography (CBCT) imaging. Several classifications of furcation defects that have been suggested were correlated to the destruction of interradicular bone septa with changes in the position of epithelial attachment, but none is complete, the most widely used being Glickman's $[3,4]$.

In the approach of the furcation treatment, the morphological and functional particularities of pluriradicular teeth must be taken into account: the presence of the thickness $(\leq 150 \mu \mathrm{m}$ to $200 \mu \mathrm{m})$ of a cellular mixed stratified cementum with Sharpey's fibers, intrinsic fibers and cells [4], the continuous deposition of the cementum for compensating teeth eruption and attrition, the presence of the interradicular fibers, the communication with dental pulp through the accessory canals, the exposure of the furcation area by gingival recession, and the alveolar bone loss [4].

Radicular morphogenesis is controlled by Hertwig's epithelial root sheath, which influences root length, number, and shape. In addition, it determines the genesis of radicular dentin, as well as intervenes in the synthesis of root cementum [5].

During the disintegration of the Hertwig's sheath, the

This is an open-access article distributed under the terms of a Creative Commons Attribution-NonCommercial-ShareAlike 4.0 International Public License, which permits unrestricted use, adaptation, distribution and reproduction in any medium, non-commercially, provided the new creations are licensed under identical terms as the original work and the original work is properly cited. 
root epithelial cells secrete proteins such as enamelin and amelogenin on the surface of the newly formed dentin. As the sheath disintegrates, the mesenchymal cells (MCs) of the dental follicle are chemotactically attracted to this protein layer and migrate to the dentin, releasing acellular cement or cell cement where Sharpey's fibers will be inserted. Other MCs differentiate into cells that form the periodontal ligament and the alveolar bone itself (this is the origin of the deep periodontium) [6].

Several factors, such as local periodontal inflammation, dento-periodontal trauma or excessive forces leading to orthodontic tooth movement cause multiple abnormalities related to a single tooth or small groups of teeth $[7,8]$. In most cases, the inflammatory reaction leads to the resorption of the root [5].

In recent years, important advances have been made in terms of tissue regeneration techniques, including periodontal tissues, an important place being occupied by enamel matrix derivatives (EMDs) and MCs.

EMDs contain proteins, especially amelogenin, extracted from porcine dental buds and are used for the potential to initiate the transformation of blood thrombus cells into cementoblasts, fibroblasts and osteoblasts, periodontal ligament formation and even induction of angiogenesis on the ability of EMD to upregulate vascular endothelial growth factor (VEGF) production by fibroblasts, with deep periodontal regeneration $[6,9,10]$.

The regenerative EMD impact on periodontal tissue can be associated with its effect on growth factors, such as transformation of bone morphogenetic proteins, transforming growth factor-beta (TGF- $\beta$ ), fibroblast growth factor, VEGF, and platelet-derived growth factor [11].

Several studies have been performed with EMD (as an alternative form of regenerative treatments) to replace guided tissue regeneration (GTR) by bioresorbable membrane, because GTR has shown unpredictable results [9]. The data obtained show the efficiency/advantage of EMD in the treatment of gingival retractions and alveolar septal resorptions, as a single material or in combination with addition biomaterials, applied through the coronary displaced flaps by classical techniques or tunneling.

\section{ㅁ PubMed search}

In the PubMed database was found 1068 articles about EMD, the oldest article dating from 1976. Of these, selecting by 'enamel matrix derivatives-periodontal' and 'enamel matrix derivatives-furcation' keywords, as it is seen in Figure 1, although most articles about EMD are related to the treatment of periodontal disease, a very small number of these, actually treat the application of EMD in furcations, the first article being published in 2003 (Figure 1). Of the 57 articles selected by entering the 'enamel matrix derivatives-furcation' keywords present in the title or abstract, only 30 articles on clinical or animal studies actually corresponded by manual search.

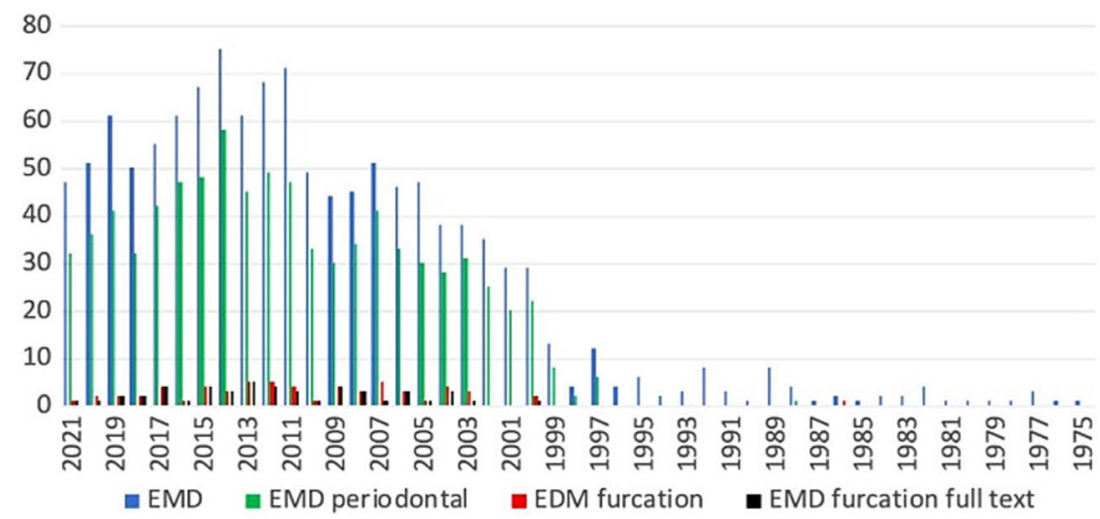

Figure 1 - PubMed publications including enamel matrix derivatives (EMDs).

Of 30 selected articles, 15 were clinical trials, eight review articles, and seven animal studies (dogs and monkeys). A review article was excluded due to a lack of information for the chosen topic.

Of 15 clinical trial articles, randomized or test-and- control, all of those published between 2003-2017, 14 studying class II furcations, mostly molar mandibular defects, four maxillary proximal molar furcations, and only one article about class III molar mandibular furcations (Table 1).

Table 1 - Publications on the use of EMDs in the treatment of periodontal disease molar furcations

\begin{tabular}{|c|c|c|c|c|c|c|}
\hline No. & $\begin{array}{c}\text { Study } \\
\text { reference }\end{array}$ & Study type & Method & Reevaluation & No./Defects & Comments \\
\hline 1. & $\begin{array}{c}\text { Masaeli et al. } \\
(2018)[12]\end{array}$ & Review & & & 28 articles & \\
\hline 2. & $\begin{array}{l}\text { Queiroz et al. } \\
\text { (2017) [13] }\end{array}$ & $\begin{array}{l}\text { Clinical trial; } \\
\text { randomized } \\
\text { controlled trial }\end{array}$ & $\begin{array}{c}\text { EMD; EMD + BGS } \\
(\beta-T C P / H A) ; B G S \\
(\beta-T C P / H A) ; \text { bacterial } \\
\text { DNA analysis }\end{array}$ & $\begin{array}{l}3 \text { and } \\
6 \text { months }\end{array}$ & $\begin{array}{l}41 \text { patients with } \\
\text { mandibular class II } \\
\text { buccal furcation; } \\
39 \text { samples }\end{array}$ & $\begin{array}{l}\beta \text {-TCP/HA } \\
\text { microbiome }\end{array}$ \\
\hline 3. & $\begin{array}{l}\text { Soares et al. } \\
(2020)[14]\end{array}$ & $\begin{array}{l}\text { Systematic review } \\
\text { and meta-analysis }\end{array}$ & & & $\begin{array}{l}\text { Five studies qualitative } \\
\text { synthesis, two for the } \\
\text { quantitative analysis }\end{array}$ & \\
\hline 4. & $\begin{array}{c}\text { Ivanovski } \\
(2009)[15]\end{array}$ & Review & & & & \\
\hline 5. & $\begin{array}{l}\text { Queiroz et al. } \\
\text { (2015) [16] }\end{array}$ & $\begin{array}{c}\text { Clinical trial - case } \\
\text { series }\end{array}$ & $\mathrm{EMD}+\beta-\mathrm{TCP} / \mathrm{HA}$ & 6 months & $\begin{array}{l}13 \text { patients' class II } \\
\text { mandibular furcation } \\
\text { (no smokers) }\end{array}$ & $\beta-\mathrm{TCP} / \mathrm{HA}$ \\
\hline
\end{tabular}




\begin{tabular}{|c|c|c|c|c|c|c|}
\hline No. & $\begin{array}{c}\text { Study } \\
\text { reference }\end{array}$ & Study type & Method & Reevaluation & No./Defects & Comments \\
\hline 6. & $\begin{array}{l}\text { Koop et al. } \\
(2012)[17]\end{array}$ & Systematic review & & & $\begin{array}{l}27 \text { studies for } \\
\text { intrabony defects } \\
\text { and recession }\end{array}$ & $\begin{array}{c}\text { One eligible study } \\
\text { on furcations } \\
\text { follow-up } \geq 1 \text { year, } \\
\text { human studies }\end{array}$ \\
\hline 7. & $\begin{array}{l}\text { Casarin et al. } \\
\text { (2010) [9] }\end{array}$ & $\begin{array}{l}\text { Randomized clinical } \\
\text { trial, double-blinded, } \\
\text { split-mouth }\end{array}$ & $\begin{array}{c}\text { OFD + EDTA, } \\
\text { OFD + EDTA + EMD }\end{array}$ & $\begin{array}{l}6,12 \text { and } \\
24 \text { months }\end{array}$ & $\begin{array}{c}12 \text { patients presenting } \\
\text { bilateral class II } \\
\text { proximal furcation, } \\
\text { maxillary molars } \\
\end{array}$ & \\
\hline 8. & $\begin{array}{l}\text { Queiroz et al. } \\
\text { (2016) [18] }\end{array}$ & $\begin{array}{l}\text { Randomized clinical } \\
\text { trial, blinded }\end{array}$ & $\begin{array}{l}\text { EMD, } \beta-\mathrm{TCP} / \mathrm{HA}, \\
\text { EMD + } \beta-\mathrm{TCP} / \mathrm{HA}\end{array}$ & 12 months & $\begin{array}{c}41 \text { patients, } \\
\text { mandibular class II } \\
\text { buccal furcation defect }\end{array}$ & $\beta-\mathrm{TCP} / \mathrm{HA}$ \\
\hline 9. & $\begin{array}{l}\text { Regazzini et al. } \\
\text { (2004) [19] }\end{array}$ & $\begin{array}{l}\text { Dogs, comparative } \\
\text { study }\end{array}$ & & & 4 dogs, 3 groups & \\
\hline 10. & $\begin{array}{l}\text { Meyle et al. } \\
(2004)[20]\end{array}$ & $\begin{array}{l}\text { Randomized clinical } \\
\text { trial }\end{array}$ & EMD, GTR & $\begin{array}{l}14 \text { months } \\
\text { reentry }\end{array}$ & $\begin{array}{l}48 \text { patients, buccal } \\
\text { class II furcation } \\
\text { involvements, first } \\
\text { and second molars }\end{array}$ & $\begin{array}{l}\text { Influence of } \\
\text { furcation } \\
\text { morphology }\end{array}$ \\
\hline 11. & $\begin{array}{l}\text { Hovey et al. } \\
(2006)[21]\end{array}$ & Baboons & & & $\begin{array}{c}6 \text { female baboons, } \\
\text { class III furcation } \\
\text { defects }\end{array}$ & \\
\hline 12. & $\begin{array}{l}\text { Casarin et al. } \\
\text { (2009) [22] }\end{array}$ & $\begin{array}{l}\text { Pearson's and } \\
\text { Spearman's rank } \\
\text { correlation tests }\end{array}$ & & 6 months & $\begin{array}{c}18 \text { class II proximal } \\
\text { furcations (maxillary } \\
\text { molars) }\end{array}$ & \\
\hline 13. & $\begin{array}{l}\text { Zhu et al. } \\
(2009)[23]\end{array}$ & Monkeys & & & $\begin{array}{c}3 \text { monkeys, } 6 \text { groups, } \\
\text { class III furcation } \\
\text { defects }\end{array}$ & \\
\hline 14. & $\begin{array}{l}\text { Jepsen et al. } \\
(2004)[24]\end{array}$ & $\begin{array}{l}\text { Randomized clinical } \\
\text { trial, split-mouth }\end{array}$ & EMD, GTR & $\begin{array}{l}14 \text { months } \\
\text { reentry }\end{array}$ & $\begin{array}{l}45 \text { patients with } 90 \\
\text { comparable class II } \\
\text { mandibular, first and } \\
\text { second molars } \\
\text { defects }\end{array}$ & $\begin{array}{l}\text { Antibiotics were } \\
\text { prescribed twice } \\
\text { after EMD surgery } \\
\text { and eight times after } \\
\text { membrane surgery }\end{array}$ \\
\hline 15. & $\begin{array}{c}\text { Fernandes } \\
\text { et al. }(2005) \\
{[25]}\end{array}$ & $\begin{array}{c}\text { Five dogs, } \\
\text { histologically and } \\
\text { histometrically test- } \\
\text { control }\end{array}$ & $\begin{array}{c}\text { EMD + bioactive glass + } \\
\text { GTR, EMD + GTR, } \\
\text { bioglass + GTR } \\
\text { (control) }\end{array}$ & & $\begin{array}{l}20 \text { teeth, } 3 \\
\text { groups, one } \\
\text { control }\end{array}$ & $\begin{array}{l}\text { One antibiotic } \\
\text { (Penicillin G) i.m. } \\
\text { administration }\end{array}$ \\
\hline 16. & $\begin{array}{l}\text { Palioto et al. } \\
(2012)[26]\end{array}$ & $\begin{array}{c}\text { Dogs, } \\
\text { histomorphometrically } \\
\text { test-control, } 12 \text { weeks }\end{array}$ & Four groups & & 6 dogs & TGF- $\beta 1$ \\
\hline 17. & $\begin{array}{l}\text { Peres et al. } \\
(2013)[27]\end{array}$ & $\begin{array}{l}\text { Randomized clinical } \\
\text { trial, double-blind }\end{array}$ & $\begin{array}{c}\text { OFD + } \beta-\mathrm{TCP} / \mathrm{HA} \\
\mathrm{OFD}+\beta-\mathrm{TCP} / \mathrm{HA}+\mathrm{EMD}\end{array}$ & 6 months & $\begin{array}{c}30 \text { patients, proximal } \\
\text { class II furcation } \\
\text { defects (maxillary } \\
\text { molars) }\end{array}$ & \\
\hline 18. & $\begin{array}{l}\text { Chitsazi et al. } \\
\text { (2007) [28] }\end{array}$ & $\begin{array}{l}\text { Clinical trial, } \\
\text { split-mouth }\end{array}$ & OFD + EMD, EMD & $\begin{array}{l}6 \text { month } \\
\text { reentry }\end{array}$ & $\begin{array}{l}20 \text { similar bilateral } \\
\text { class II furcation } \\
\text { defects in } 10 \text { patients }\end{array}$ & $\begin{array}{c}\text { Healthy } \\
\text { nonsmoker }\end{array}$ \\
\hline 19. & $\begin{array}{l}\text { Jaiswal \& Deo } \\
\text { (2013) [29] }\end{array}$ & $\begin{array}{l}\text { Randomized clinical } \\
\text { trial }\end{array}$ & $\begin{array}{c}\text { EMD + BGS + GTR } \\
\text { BGS + GTR } \\
\text { OFD }\end{array}$ & 12 months & $\begin{array}{c}30 \text { patients, } \\
\text { mandibular class II } \\
\text { furcation defects }\end{array}$ & $\begin{array}{l}\text { Bone allograft, } \\
\text { computerized } \\
\text { probe, post-surgery: } \\
\text { non-steroidal anti- } \\
\text { inflammatory } \\
\text { medication and } \\
\text { systemic antibiotics }\end{array}$ \\
\hline 20. & $\begin{array}{l}\text { Donos et al. } \\
(2003)[30]\end{array}$ & $\begin{array}{c}\text { Clinical trial case } \\
\text { series }\end{array}$ & EMD & $\begin{array}{l}6,12, \text { and } \\
36 \text { months }\end{array}$ & $\begin{array}{l}10 \text { patients, } \\
\text { mandibular } \\
\text { degree II } \\
\text { furcation }\end{array}$ & $\begin{array}{c}0.2 \% \text { Chlorhexidine } \\
\text { digluconate three } \\
\text { times per day, } \\
\text { six weeks } \\
\text { postoperative } \\
\end{array}$ \\
\hline 21. & $\begin{array}{c}\text { Hoffmann } \\
\text { et al. (2006) } \\
{[31]}\end{array}$ & $\begin{array}{l}\text { Randomized clinical } \\
\text { trial }\end{array}$ & EMD; GTR & $\begin{array}{l}14 \text { months } \\
\text { reentry }\end{array}$ & $\begin{array}{c}48 \text { patients, buccal } \\
\text { class II furcation, } \\
\text { first and second } \\
\text { molars }\end{array}$ & $\begin{array}{c}\text { Influence of } \\
\text { smoking, age, } \\
\text { gender, } \\
\text { hypertension, and } \\
\text { oral hygiene status }\end{array}$ \\
\hline 22. & $\begin{array}{l}\text { Casarin et al. } \\
(2008)[32]\end{array}$ & $\begin{array}{c}\text { A double-blind } \\
\text { randomized clinical trial, } \\
\text { randomized controlled } \\
\text { trial }\end{array}$ & & $\begin{array}{l}2,4 \text { and } \\
6 \text { months }\end{array}$ & $\begin{array}{l}15 \text { patients, control } \\
\text { group, proximal } \\
\text { class II furcation } \\
\text { (maxillary molars) }\end{array}$ & \\
\hline 23. & $\begin{array}{l}\text { Donos et al. } \\
(2004) \text { [33] }\end{array}$ & Clinical trial & $\begin{array}{l}\text { EMD, GTR, } \\
\text { EMD + GTR }\end{array}$ & $\begin{array}{l}6 \text { and } 12 \\
\text { months }\end{array}$ & $\begin{array}{c}9 \text { patients, } \\
\text { class III mandibular } \\
\text { furcation }\end{array}$ & \\
\hline 24. & $\begin{array}{l}\text { Aimetti et al. } \\
\text { (2007) [34] }\end{array}$ & & $\begin{array}{l}\text { EMD + BGS } \\
\text { (autologous) }\end{array}$ & 24 months & $\begin{array}{l}11 \text { patients, class II } \\
\text { furcation defects }\end{array}$ & $\begin{array}{l}\text { Vital molars with a } \\
\text { minimum of } 2 \mathrm{~mm} \\
\text { of keratinized } \\
\text { tissue, autologous } \\
\text { bone grafts }\end{array}$ \\
\hline
\end{tabular}




\begin{tabular}{|c|c|c|c|c|c|c|}
\hline No. & $\begin{array}{c}\text { Study } \\
\text { reference }\end{array}$ & Study type & Method & Reevaluation & No./Defects & Comments \\
\hline 25. & $\begin{array}{l}\text { Oliveira et al. } \\
(2020)[35]\end{array}$ & $\begin{array}{l}\text { Systematic review } \\
\text { and meta-analysis, } \\
\text { a minimum follow-up } \\
\text { of } 12 \text { months }\end{array}$ & & & $\begin{array}{l}19 \text { studies, } \\
618 \text { patients }\end{array}$ & \\
\hline 26. & $\begin{array}{c}\text { Sculean et al. } \\
(2007) \text { [36] }\end{array}$ & Review & & & & \\
\hline 27. & $\begin{array}{l}\text { Trombelli \& } \\
\text { Farina } \\
(2008)[37]\end{array}$ & Review & & & & \\
\hline 28. & $\begin{array}{c}\text { Shirakata } \\
\text { et al. (2017) } \\
{[38]}\end{array}$ & $\begin{array}{c}\text { Monkeys, } 16 \text { weeks, } \\
\text { histomorphometric } \\
\text { analysis }\end{array}$ & & & $\begin{array}{c}3 \text { monkeys, } \\
12 \text { mandibular } \\
\text { defects }\end{array}$ & \\
\hline 29. & $\begin{array}{c}\text { Mardas et al. } \\
(2012)[39]\end{array}$ & $\begin{array}{c}\text { Comparative study, } \\
\text { test-control, dogs, } \\
5 \text { months }\end{array}$ & & & $\begin{array}{l}9 \text { dogs, } 17 \text { class III } \\
\text { furcation defects }\end{array}$ & \\
\hline 30. & $\begin{array}{c}\text { Heard \& } \\
\text { Mellonig } \\
(2000)[40]\end{array}$ & Review & & & $\begin{array}{l}\text { Maxillary class II } \\
\text { furcations }\end{array}$ & Excluded \\
\hline
\end{tabular}

$\beta$-TCP/HA: beta-Tricalcium phosphate/Hydroxyapatite; BGS: Bone graft substitute; DNA: Deoxyribonucleic acid; EDTA: Ethylenediaminetetraacetic acid; EMD: Enamel matrix derivative; GTR: Guided tissue regeneration; i.m.: Intramuscular; OFD: Open flap debridement; TGF- $\beta 1$ : Transforming growth factor-beta 1.

\section{Clinical studies}

\section{Mandibular furcations class III}

In 2004, Donos et al. come with a comparative study on nine patients with 14 defects, namely class III mandibular furcation involvement and the outcomes were monitored after six and 12 months through measuring the level of probing attachment in the vertical and horizontal directions at the furcation place after treatment with (i) EMD (four defects); (ii) three defects with a bioresorbable membrane (GTR); and (iii) combination of EMD and GTR (seven defects) $[30,33]$. In all cases, an improvement in the values of the indices was obtained. Partial closure has occurred in mainly half of the treated furcations, where teeth presented through-and-through furcation lesion and when vertical probing followed, the level was consistently improved. GTR used single or in combination with EMD led to a lower number of partial closures, but the small number of patients included in the study did not allow a conclusion to be drawn about the efficacy and predictability of the methods used [33].

\section{Mandibular furcations class II}

The first published clinical study using EMD for surgical therapy of furcations was found in 2003, which contained a clinical trial of 10 patients with evaluation at six, 12, and 36 months after the application of an EMD in class II mandibular furcation defect [30]. Clinical parameters were evaluated: probing attachment level in the lingual and/or buccal furcation area on a horizontal direction (PAL-H), and probing attachment level at the center of lingual/buccal furcation area on vertical direction (PAL-V) [30]. The results showed an improvement in terms of clinical parameters at six months, and the values remained unchanged at 12 and 36 months. A greater reduction of the average values of PAL-H was registered at the buccal defects compared to the lingual defects, and PAL-V had approximately equal average reductions for these two types of defects [30].

The following studies using EMD in class II mandibular furcations were performed by Jepsen et al. (2004) [24], Meyle et al. (2004) [20], and Hoffmann et al. (2006) [31].
They were split-mouth comparative studies that showed the efficacy of EMD compared with GTR by bioabsorbable membranes.

Jepsen et al. (2004) published a randomized splitmouth clinical trial, a part I study which included 45 subjects with 90 similar defects on the contralateral molars. Defects were randomly assigned (RAS) to EMD (test sites) or bioabsorbable barrier membrane (control sites) [24]. The clinical parameters measured at baseline, eight and 14 months, respectively, were: vertical attachment levels (ALs), probing depths (PDs), gingival margin (GM) levels, bleeding on probing (BOP), and vertical bone sounding (BS) related to a stent at five buccal places/ tooth. Dimensions of defect were registered at surgery as well as to reentry at 14 months. The primary outcome variable was represented by change of horizontal open furcation depth, and the study showed a significantly greater reduction of horizontal furcation depth in the EMD sites $(78 \%)$ than those with a membrane $(67 \%)$. Also, EMD therapy had a better degree of prediction comparable to GTR, as most defects were completely closed (eight defects compare to three) and fewer defects deteriorated (one defect compared to four) [24].

After the surgery, the authors mentioned as side effects pain and swelling with the lower occurrence in the EMDtreated group.

Also, there were notable differences in antibiotics needed prescription: eight times after the membrane surgery and twice after the EMD surgery [24].

Meyle et al., in 2004, included 48 patients from five centers, in a randomized trial (part II study), and made a comparison between EMD and barrier membranes for therapy of class II mandibular furcation in both contralateral lower first or second [20]. In addition, it was studied if the root morphology has implications in the modification of the post-treatment values. The clinical study was absolute after a 14 months of reentry surgery [20]. The main parameters pursued measurements and records of the hard tissue boundaries, which are describing the anatomical status of furcation defect, as well as secondary parameters: level of GM, AL, PD, and BS at five places/tooth from the buccal side: mid-mesial root, mesio-buccal, mid-distal 
root, mid-furcation and disto-buccal [20]. The Wilcoxon two-sample test was used to analyze the differences between the two methods and the Hodges-Lehmann estimator. Even if similar results were obtained, a higher probability of gingival retractions was detected in the area corresponding to the center of the furcation, in the case of the treatment which used membranes $(p=0.04)$ [20]. No measurable bone resorption was recorded at sites where EMD was added, but instead, slight resorptions were observed with membrane treatment [20]. In addition, the study showed that the furcation morphology was not associated with clinical outcomes at the time of surgery, irrespective of the treatment [20].

Hoffmann et al. (2006) studied 48 patients, including smokers with buccal degree II furcation defects in mandibular first or second molars [31]. Each patient had surgery on both left and right sides, with EMD and respectively GTR with a bioresorbable membrane and more monitoring with a reentry at 14 months after the surgery [31]. Parameters followed: changes in all anatomical dimensions of hard tissue boundaries in the furcation defect, horizontal depth of the furcation defect that is measured from the deepest point both during surgery and reentry, AL, bleeding, pocket depth, level of GM, BS and classification of lingual and buccal furcation defect. Additionally, the possible influence of the treatment results of the following factors were taken into consideration: smoking, age, gender, hypertension, and oral hygiene status [31].

Results showed a higher median reduction of the horizontal depth of defect placed at the deepest point in nonsmokers for sites treated with EMD comparing with sites treated by membrane ( 2.75 versus 1.75$)$, an inappreciable advantage of regenerative furcation treatment when it used EMD versus membranes therapy, in male patients of the older age group, in non-smokers, and patients with poor hygiene [31].

In 2007, Chitsazi et al. evaluated the effectiveness of open flap debridement (OFD) using or not EMD in the therapy of class II furcation involvement to 10 non-smoker patients with 20 similar bilateral class II furcation defects, a split-mouth study [28].

There were investigated soft parameters of tissue: clinical probing depth (CPD) and horizontal and vertical clinical attachment level (HCAL and VCAL), as well as hard parameters of tissue, such as:

(1) Surgically exposed of the horizontal probing depths (HPDs) of the bony defect: the horizontal distance was appreciated between the deepest probed region of defects and the corresponding rubber stop contacting the root convexity, all this while the probe is relatively perpendicular to the long axis of the tooth;

(2) Vertical depth of the bone crest: appreciated by the vertical distance between lower border of the template and the alveolar crest;

(3) Vertical depth related to the base of bony defect (V-DBD): appreciated by the vertical distance between base of bony defect and lower border of template;

(4) Length corresponding to the intrabony defect (LID): the vertical distance between base of bony defect and alveolar crest [28].

The results indicated a greater improvement in the investigated indices in the EMD group, VCAL had a 13\% increase in the EMD group compared to $8.3 \%$ in OFD, but without statistically significant differences between the two groups at six months. The evaluation of soft parameters of tissue showed that addition of EMD significantly improved the horizontal attachment gain by $1.2 \mathrm{~mm} \mathrm{(30 \% )}$ for EMD more than OFD [28].

The conclusion of the study was the fact that the use of EMD caused a substantial enhancement of the HCAL and more efficient generation of new bone both horizontally and vertically [28].

Also, in 2007, Aimetti et al. published a study on 11 individuals, two years in evaluation of treatment, this time with a combination of autologous bone grafts and EMD in buccal mandibular class II furcation defects of vital molars presenting at least $2 \mathrm{~mm}$ of keratinized tissue [34]. The results were evaluated clinically and radiologically and showed the reduction of defects from class II to class I in seven patients, four patients presenting a complete closure of the defect [34].

The next study found on PubMed in which the combination of EMD with bone graft substitute (BGS) was used was that of Jaiswal \& Deo (2013) who followed in randomized controlled trial study effectiveness of EMD in association with freeze-dried demineralized bone allograft (BGS) but also with bioresorbable membranes $\left(\right.$ BioMesh $\left.^{\circledR}\right)$ [29]. Thirty systemically healthy patients were selected with the presence of a single class II buccal/lingual furcation defect on mandibular molars as determined by clinical and radiographic evaluation, GM, positioned coronally to the furcation fornix [29]. Three groups were RAS using computer software: EMD + BGS + GTR, BGS + GTR, and OFD [29]. Evaluations were performed at six and 12 months post-surgery, following several indices: HPD, vertical probing pocket depth (PPD), relative GM level (RGML) and vertical relative attachment level (VRAL) [29]. The difference from other studies was that the recordings were made with a computerized probe (except HPD) and at the level of the furcations, the average of three determinations was considered: the mesial, the distal and the mid-buccal/mid-lingual angles.

Another difference of this study compared to others, was the postoperative attitude, in addition to oral rinsing with $0.2 \%$ Chlorhexidine gluconate, twice daily, four to six weeks, patients were prescribed a nonsteroidal antiinflammatory medication (Ibuprofen + Paracetamol) for five days and systemic antibiotics (Amoxicillin $500 \mathrm{mg}$, three times daily) for seven days [29].

The results showed significant reduction of the parameters when EMD + BGS + GTR were used, comparing with BGS + GTR and OFD. In all groups there was a reduction in PD of $1.74 \pm 1.00 \mathrm{~mm}, 0.81 \pm 0.31 \mathrm{~mm}$, and $0.46 \pm 0.52 \mathrm{~mm}$, 12 months after surgical therapy. The gain of vertical attachment to the group where EMD was used was $2.12 \pm 1.07 \mathrm{~mm}$ compared to the other groups. Complete furcation closure was observed in $30 \%$ of cases (three) for $\mathrm{EMD}+\mathrm{BGS}+\mathrm{GTR}$, and $0 \%$ for BGS + GTR and OFD. A partial closure (class I) for the class II furcation defects was observed in $70 \%$ of cases (seven) after EMD + BGS + GTR, $80 \%$ of defects (eight) after BGS + GTR and 20\% of defects (two) after OFD. No defects remained as class II in the EMD + BGS + GTR places, $20 \%$ of defects (two) remained unchanged for BGS + GTR sites and $80 \%$ (eight) for OFD [29]. 
Better results by using the combination of EMD with GTR was explained by the authors by providing space for the regeneration of cells and support plus wound protection at the furcation place during healing process [29].

Conclusions of this particular study were that EMD + BGS + GTR and BGS + GTR, proved statistically significant increased results in terms of V-RAL gain, reduction of HPD, PPD and that EMD + BGS + GTR caused a statistically significant reduction of V-RAL, PPD and non-significantly important reduction of HPD, compared to BGS + GTR [29].

Regarding the study of the association of EMD with beta-Tricalcium phosphate/Hydroxyapatite $(\beta$-TCP/HA) in the class II mandibular furcations, three studies of Queiroz et al. were found, conducted between 2015-2017 $[13,16,18]$.

In 2015, Queiroz et al. published a study on 13 patients: 30 days after professional hygiene, including scaling and scaling and root planning, furcations on mandibular molars with pockets $>4 \mathrm{~mm}$ and retraction $<2 \mathrm{~mm}$, used EMD $\left(\right.$ Emdogain $^{\circledR}$ ) and $\beta$-TCP/HA, applied full thickness flap after horizontal incision, without vertical incisions (avoid vertical realizing incision) and suture [16]. The reassessment was made six months after the intervention, for the following parameters: PD, relative VCAL (RVCAL), relative GM position (RGMP), and relative HCAL (RHCAL) [16]. Thus, an improvement was obtained in all situations, except in the position of the free GM, in $76.92 \%$ of patients the forks became class I. Only $23.08 \%$ furcation remained as class II, with especially the gain of horizontal AL [16].

In 2016, Queiroz et al. published a study on 41 patients when it followed the changes in the fork in three study groups: only EMD (13 patients), $\beta$-TCP/HA (14 cases), and $\mathrm{EMD}+\beta$-TCP/HA [18]. Clinical parameters measured at baseline and after six and 12 months of treatment were as follows: plaque index (PI), PPD, RVCAL and RHCAL, gingival index (GI), and RGMP [18]. At 12 months, no differences were observed between groups in relation to the level of the free GM, but significant differences were observed between the PDs and the level of vertical and horizontal attachment [18]. Horizontal attachment gain was without significant differences between groups: $2.64 \pm 0.93 \mathrm{~mm}$ for $\beta$-TCP/HA, $2.77 \pm 0.93 \mathrm{~mm}$ for EMD, and $2.93 \pm 0.83 \mathrm{~mm}$ for EMD $+\beta$-TCP/HA. At the study end, $85.3 \%$ of the places were partially closed, but no complete closure was noted [18].

In 2017, Queiroz et al. returned with the study of the association of EMD and $\beta$-TCP/HA from the perspective of the effect on the microbiocenosis of the furcations [13]. They performed a randomized study with baseline monitoring, three and six months [13]. In 39 patients with grade II buccal forceps in the mandible, divided into three groups, they compared the changes in microbial flora following furcation treatment with EMD alone, in association with a BGS composed of $\beta$-TCP/HA, or only bone substitute [13]. The results of the study showed that there are differences in the composition of the microbial flora in the approximate areas and furcations - the complex microbiome of the furcation, as well as greater heterogeneous sites, rather than interproximal sites [13]. More than that, a significant finding was that although species like Porphyromonas (P. gingivalis) and Treponema (T. denticola) were found in the furcation defects, these were not even a slight part of the microbiome core of the furcations [13]. Although similar results were obtained in terms of regeneration of furcation defects, in patients with EMD in treatment a longer microbiome stability was obtained with decreasing pathogen richness and increasing commensal abundance [13].

\section{Maxillary furcations}

The treatment of maxillary furcations was less studied, in PubMed there were four studies, three performed by Casarin et al. and published in 2008 [32], 2009 [22], 2010 [9] and one by Peres et al. in 2013 [27].

In 2008, Casarin et al. published a randomized, doubleblind study that evaluated the clinical outcomes of proximal furcations treated by EMD proteins in 15 patients, each with a pair of the contralateral class II proximal furcation implications [32]. The parameters followed immediately before the intervention, at two and four months after intervention were: BOP, PI, PD, RHCAL and RVCAL, GM position, furcation closure and horizontal and vertical bone level (HBL and VBL). The test-group sites: after mucoperiosteal flaps raised at the level of palatine and buccal root surfaces were conditioned using 24\% Ethylenediaminetetraacetic acid (EDTA) gel + EMD compared to control group site without EMD association [32]. The results of the study do not show differences in the reduction of PD and the gain in clinical and osseous ALs between the two groups, but in the site where EMD was used, a greater transformation of furcations from class II to class I was observed, two proximal furcations were not detectable. By clinical examination, only $33 \%$ were class II furcations, compared to $67 \%$ in the control group, without total closures [32].

In 2010, Casarin et al. published a continuation of the study from 2008, but with follow-up at two years: a doubleblind, split-mouth randomized and prospective controlled clinical study [9]. It included 12 patients (three patients were lost from the 2008 study) with class II, proximal bilateral furcation defects, patients presenting the same treatment: on one hemiarcade performed only OFD with 24\% EDTA root conditioning (control group) and on the other arch also associated EMD (test group) [9]. At two years, there was a greater improvement of the bone support in the proximal furcation area in the group treated with EMD, with the transformation of a larger number of furcations in class I, only five furcations remaining class II, in two cases obtaining total closure, compared to the control group in which 10 furcations remained class II, none closing completely [9]. The other parameters investigated were not statistically changed between groups [9].

Casarin et al. studied in 2009 the influence of anatomical features and defect morphology on maxillary molars in the treatment with EMD [22]. A selected 18 patients with proximal furcations class II were treated with OFD + $24 \%$ EDTA conditioning + EMD proteins. The parameters analyzed before and six months after the intervention were PD, RHCAL and RVCAL, GM position, and horizontal and vertical bone levels were correlated with the depth defect, vertical defect, interdental distance, number of walls, furcation distance, root divergence, root measure, furcation height, root trunk, with the help of Pearson's 
and Spearman's rank tests [22]. The conclusion was that the furcation and the defect of morphology influence clinical response of the EMD-based protein therapy in the involvement of class II proximal furcations [22].

Peres et al., in 2013, included in a prospective double blind, controlled, parallel and randomized clinical study, thirty patients who presented at least one proximal defect of class II furcation, with PPD $\geq 5 \mathrm{~mm}$ and BOP [27]. The results obtained from the two types of treatment were compared: after OFD $+\beta$-TCP/HA filling $(\beta$-TCP/HA group $)$ and $\mathrm{OFD}+\beta$-TCP $/ \mathrm{HA}+\mathrm{EMD}$ filling $(\beta$-TCP/HA + EMD group). The clinical parameters were evaluated both at baseline and six months post-surgical procedure, including: GI, full-mouth PI, BOP, PPD, RGMP, RHCAL, RVCAL, relatively HBL (RHBL), relatively VBL (RVBL) [27].

The mean PPD and RHCAL were not statistically different at baseline between the groups. At six months, in both groups were observed an increase in gingival recession, and reduction in PPD with a significant improvement in both RVBL and RHBL [27]. Regarding furcation defects resolution, both $\beta$-TCP/HA-EMD and $\beta$-TCP/HA groups presented $46.6 \%$ and $26.6 \%$ of the furcation closure, $46.6 \%$ and $66.5 \%$ being converted to class I, while a single lesion in each group remained in the same class II [27].

The conclusion of the study was that both treatments might represent an option for therapeutic approach of proximal class II furcation defects, although no specific correlation of complete closure may be related to any form of the therapy [27].

\section{Animal studies}

Of the seven published studies in animals, four were in dogs and three in monkeys, six on the use of EMD in class III defects and one on class II defects.

Studies in dogs have evaluated histological and histometric effects of EMD use compared to coronally repositioned flaps or membrane association and TGF- $\beta 1$, as well as comparative studies of the association of EMD with absorbable membranes and bioactive glass $\left(\right.$ PerioGlas $\left.^{\circledR}\right)$ [19, 25, 26, 39].

The conclusions of the studies were:

- The EMD caused a significant regeneration of the periodontal defect furcations, while associating it with membranes appears to be detrimental [19];

- The use of EMD has not shown a benefit compared to a coronally advanced flap but appears to present a protective role against ankylosis in such kind of defect [39];

- EMD + absorbable membrane \pm bioactive glass led to similar results to those that used bioactive glass $\left(\right.$ PerioGlas $\left.{ }^{\mathbb{R}}\right)+$ absorbable membrane, with partial filling of the respective furcations and bone and cement regeneration that is limited to apical portion of the defects [25];

- There is not histological evidence that EMD, TGF- $\beta 1$ and EMD + TGF- $\beta 1$ present some additional advantages in periodontal bone synthesis in a dog model of class III furcation, these materials promote limited periodontal regeneration, but the new cementum and new bone formation were greater when used EMD and TGF- $\beta 1$ [26].

Factors that can influence formation of new cement are as followed: the size of the defect, the presence of remaining original cementum on the roots, the presence of gingival recession, the level of epithelial migration, the observation time of the study and the occurrence of trauma in the site during the healing period [25]. Also, the advantages of acellular matter over the cellular cementum favoring periodontal regeneration are not yet fully known, EMD has a role in the formation of new layer of cementum.

Three studies on monkeys were included in this review. In 2006, Hovey et al. studied six female baboons which received $10 \mathrm{~mm}$ bilateral ostectomy around the first and second mandibular molars to obtain class III, subclass C furcation defects [21]. There were investigated six total sites per treatment group to one of four treatments: OFD, OFD + bioengineered tissue (Dermagraft $\left.{ }^{\mathbb{R}}-\mathrm{DG}\right), \mathrm{OFD}+$ EMD, or OFD + bioengineered tissue (DG) and EMD [21]. Seven months after creation of the defect and five months after the therapy, and without oral hygiene, histometric analysis demonstrated differential regenerative responses, EMD-treated sites presenting moderate positive regenerative outcomes and no negative responses [21]. DG alone or in combination therapy led to similar or less than positive outcomes relative to OFD controls [21].

The other two studies were performed on three monkeys (Macaca fascicularis). Zhu et al. (2009) created six defects and wanted to show the effect of periodontal ligament cells (PDLCs) (autogenous PDLCs were cultured in vitro with Bio-Oss ${ }^{\circledR}$ Collagen) with or without EMD influences periodontal tissue repair in class III furcation defects [23]. The conclusion was that separately, the two materials may increase the repair of periodontal tissue around class III furcation defects, but their combination did not have a predictable result, and the treatment may be influenced by the sizes of furcal defects and the coverage of gingival flap wound [23].

Shirakata et al., in 2017, evaluated the effect of a new system of liquid carrier of EMD (Osteogain ${ }^{\circledR}$ ) that was soaked on an absorbable collagen sponge (ACS) [38]. They studied 12 class III furcation defects created in the molars of three monkeys and depending on the applied treatment they created four groups: ( $i$ ) OFD + ACS, (ii) OFD + Emdogain $^{\circledR} / \mathrm{ACS}$, (iii) OFD + Osteogain ${ }^{\circledR} / \mathrm{ACS}$, and (iv) OFD alone [38]. The study concluded that Osteogain ${ }^{\circledR}$ has favorable physicochemical characteristics favoring adsorption of amelogenin on ACS, and additionally may also enhance the periodontal wound healing (regeneration) when it is compared to Emdogain ${ }^{\circledR}$ [38].

Regarding the review articles, in the seven articles included, which were published between 2007 and 2020, the results are in line with those found in this review, with the mention that we also included animal studies.

In 2007, in the review of Sculean et al. [36] about Emdogain ${ }^{\circledR}$ in regenerative periodontal therapy, they included studies made by Jepsen et al. [24] and Meyle et al. [20], in 2004, and concluded that the application of EMD may improves periodontal regeneration in class II mandibular furcations, clinical results being comparable to those obtained after GTR.

Ivanovski, in 2009 [15], remarked that in periodontal regeneration, there were no randomized and controlled clinical trials to compare EMD with OFD in the therapy of furcation defects and mentions the results of Jepsen et al. (2004) study [24].

In the review of Trombelli \& Farina, in 2008, limited evidence supports the use of bioactive agents either alone 
or in specific association with graft/GTR for the treatment of furcation defects [37].

Moreover, in 2012, Koop et al. [17] did a meta-analysis performed for intrabony defects and recession, a randomized controlled clinical trial with a follow-up $\geq 1$ year. Out of 27 studies in PubMed, only one was eligible about furcations, which was the one of Jepsen et al. (2004) [24], presented in our review.

In 2018, Masaeli et al. [12] finally selects 11 articles from PubMed/MEDLINE, ScienceDirect, and EMBASE and realized a systematization of studies according to the ways of using EMD alone or in association with BGS or GTR. In conclusions, it emphasizes the advantage of associating EMD in horizontal attachment gain, especially number of furcation conversions from class II to class I, stimulates the healing of soft tissues and accelerates tissue repair, a synergic effect, and boosts osteogenesis, when used in combination with bone graft and even pain and swelling minimization due to its antibacterial and antiinflammatory nature [12].

In 2020, two systematic review and meta-analysis studies appeared on the use of the EMD in the therapy of class II furcation, available on PubMed. The one by Soares et al. [14] included five studies for the qualitative synthesis, as well as two for the quantitative analysis and the other by Oliveira et al. [35] selected 19 studies. The conclusions of both meta-analyzes were that EMD does not bring additional benefits and further studies are needed.

\section{Conclusions}

Although the regenerative role of EMD in bone lesions has been extensively studied, there are few studies that have used EMD in the treatment of furcation defects. The topmost studied defects were class II mandibular furcations, except the maxillary ones, where in fact, it is significant to find alternatives to the use of membranes, which are difficult to use due to the root morphology of the maxillary molars. Besides, the analysis of the studies showed a diversity of EMD use, not only singularly, but also in association with resorbable membranes, BGS and $\beta$ TCP/HA, but few studies (three) followed the treatment results after one year. At these furcations defects, there were also changes in the microbiome compared to the one contained in the periodontal pockets. The use of EMD has led to a greater reduction in the depth of grade II furcations, compared to surgical procedures using resorbable membranes. Postoperative pain and inflammation were lower when using bone morphogenetic proteins. The clinical results obtained with the use of EMD in the treatment of grade II maxillary furcations, were inferior compared to those obtained in the treatment of mandibular furcations. Studies on animals are few, but have allowed histological analysis, so in the therapy of furcation defects grade II in dogs, a corresponding regeneration of the defects was observed in cases where only EMD was used, without the presence of membranes. The use of EMD in periodontal regenerative therapy is an important choice in the complex treatment of destructive periodontal disease and requires further studies in periodontal regeneration.

\section{Conflict of interests}

The authors declare that they have no conflict of interests.

\section{Author contribution}

Andreea Cristiana Didilescu has equal contributions to this paper as the first author.

\section{References}

[1] Tonetti M. Time to take gum disease seriously: the societal and economic impact of periodontitis. European Federation of Periodontology (EFP), The Economist Intelligence Unit Report, 2021, 7. https://impact.economist.com/perspectives/ sites/default/files/eiu-efp-oralb-gum-disease.pdf

[2] Svärdström G, Wennström JL. Furcation topography of the maxillary and mandibular first molars. J Clin Periodontol, 1988, 15(5):271-275. https://doi.org/10.1111/j.1600-051x.1988.tb01 583.x PMID: 3164728

[3] American Academy of Periodontology (AAP). Glossary of periodontal terms. $4^{\text {th }}$ edition, AAP, Chicago, IL, USA, 2001. https://c2-preview.prosites.com/131747/wy/docs/Glossary\% 200f\%20Periodontal\%20Terms.pdf

[4] Newman MG, Takei HH, Klokkevold PR, Carranza FA (eds). Newman and Carranza's clinical periodontology. $13^{\text {th }}$ edition, Elsevier-Saunders, Philadelphia, PA, USA, 2018. https://www. elsevier.com/books/newman-and-carranzas-clinical-periodon tology/newman/978-0-323-52300-4

[5] Luder HU. Malformations of the tooth root in humans. Front Physiol, 2015, 6:307. https://doi.org/10.3389/fphys.2015.00307 PMID: 26578979 PMCID: PMC4621611

[6] Zucchelli G, Mazzotti C, Mounssif I, Mele M, Stefanini M, Montebugnoli L. A novel surgical-prosthetic approach for soft tissue dehiscence coverage around single implant. Clin Oral Implants Res, 2013, 24(9):957-962. https://doi.org/10.1111/ clr.12003 PMID: 22924841

[7] Andreasen JO. Challenges in clinical dental traumatology. Endod Dent Traumatol, 1985, 1(2):45-55. https://doi.org/10. 1111/j.1600-9657.1985.tb00560.x PMID: 3861314

[8] Tronstad L. Root resorption - etiology, terminology and clinical manifestations. Endod Dent Traumatol, 1988, 4(6):241-252. https://doi.org/10.1111/j.1600-9657.1988.tb00642.x PMID: 3078294

[9] Casarin RCV, Del Peloso Ribeiro E, Nociti FH Jr, Sallum AW, Ambrosano GMB, Sallum EA, Casati MZ. Enamel matrix derivative proteins for the treatment of proximal class II furcation involvements: a prospective 24-month randomized clinical trial. J Clin Periodontol, 2010, 37(12):1100-1109. https:// doi.org/10.1111/j.1600-051X.2010.01614.x PMID: 20735795

[10] Thoma DS, Villar CC, Carnes DL, Dard M, Chun YHP, Cochran DL. Angiogenic activity of enamel matrix derivative (EMD) and EMD-derived proteins: an experimental study in mice. J Clin Periodontol, 2011, 38(3):253-260. https://doi.org/ 10.1111/j.1600-051X.2010.01656.x PMID: 21198764

[11] Kulakauskienè R, Aukštakalnis R, Šadzevičienè R. Enamel matrix derivate induces periodontal regeneration by activating growth factors: a review. Stomatologija, 2020, 22(2):49-53. PMID: 33245062

[12] Masaeli R, Zandsalimi K, Lotfi Z, Tayebi L. Using enamel matrix derivative to improve treatment efficacy in periodontal furcation defects. J Prosthodont. 2018, 27(8):733-736. https:// doi.org/10.1111/jopr.12753 PMID: 29322600

[13] Queiroz LA, Casarin RCV, Dabdoub SM, Tatakis DN, Sallum EA, Kumar PS. Furcation therapy with enamel matrix derivative: effects on the subgingival microbiome. J Periodontol, 2017, 88(7):617-625. https://doi.org/10.1902/jop.2017.160542 PMID: 28304211

[14] Soares DM, de Melo JGA, Barboza CAG, Alves RV. The use of enamel matrix derivative in the treatment of class II furcation defects: systematic review and meta-analysis. Aust Dent J, 2020, 65(4):241-251. https://doi.org/10.1111/adj.12794 PMID: 32929749

[15] Ivanovski S. Periodontal regeneration. Aust Dent J, 2009, 54(Suppl 1):S118-S128. https://doi.org/10.1111/j.1834-7819. 2009.01150.x PMID: 19737264

[16] Queiroz LA, Santamaria M, Casati M, Silverio K, Nociti-Junior F, Sallum E. Enamel matrix protein derivative plus synthetic bone substitute for the treatment of mandibular Class II furcation defects: a case series. Quintessence Int, 2015, 46(3):199205. https://doi.org/10.3290/j.qi.a32988 PMID: 25386635 
[17] Koop R, Merheb J, Quirynen M. Periodontal regeneration with enamel matrix derivative in reconstructive periodontal therapy: a systematic review. J Periodontol, 2012, 83(6):707-720. https:// doi.org/10.1902/jop.2011.110266 PMID: 22050544

[18] Queiroz LA, Santamaria MP, Casati MZ, Ruiz KS, Nociti F Jr, Sallum AW, Sallum EA. Enamel matrix protein derivative and/or synthetic bone substitute for the treatment of mandibular class II buccal furcation defects. A 12-month randomized clinical trial. Clin Oral Investig, 2016, 20(7):1597-1606. https:// doi.org/10.1007/s00784-015-1642-x PMID: 26556577

[19] Regazzini PF, Novaes AB Jr, de Oliveira PT, Palioto DB, Taba M Jr, de Souza SL, Grisi MF. Comparative study of enamel matrix derivative with or without GTR in the treatment of class II furcation lesions in dogs. Int J Periodontics Restorative Dent, 2004, 24(5):476-487. https://doi.org/10.11607/prd.00.0600 PMID: 15506029

[20] Meyle J, Gonzales JR, Bödeker RH, Hoffmann T, Richter S, Heinz B, Arjomand M, Reich E, Sculean A, Jepsen K, Jepsen S. $A$ randomized clinical trial comparing enamel matrix derivative and membrane treatment of buccal class II furcation involvement in mandibular molars. Part II: secondary outcomes. J Periodontol, 2004, 75(9):1188-1195. https://doi.org/10.1902/jop.2004.75. 9.1188 PMID: 15515332

[21] Hovey LR, Jones AA, McGuire M, Mellonig JT, Schoolfield J, Cochran DL. Application of periodontal tissue engineering using enamel matrix derivative and a human fibroblast-derived dermal substitute to stimulate periodontal wound healing in Class III furcation defects. J Periodontol, 2006, 77(5):790-799. https://doi.org/10.1902/jop.2006.030264 PMID: 16671870

[22] Casarin RCV, Del Peloso Ribeiro E, Ribeiro FV, Nociti FH Jr, Sallum AW, Sallum EA, Casati MZ. Influence of anatomic features on the effectiveness of enamel matrix derivative proteins in the treatment of proximal Class II furcation involvements. Quintessence Int, 2009, 40(9):753-761. PMID: 19862402

[23] Zhu WD, Hou JX, Liu KN, Meng HX, Tang XL. [Clinical and radiographic evaluation of class III furcation defects in the treatment using autogenous periodontal ligament cells with or without enamel matrix derivatives]. Beijing Da Xue Xue Bao Yi Xue Ban, 2009, 41(1):56-61. PMID: 19221566

[24] Jepsen S, Heinz B, Jepsen K, Arjomand M, Hoffmann T, Richter S, Reich E, Sculean A, Gonzales JR, Bödeker RH, Meyle J. A randomized clinical trial comparing enamel matrix derivative and membrane treatment of buccal Class II furcation involvement in mandibular molars. Part I: Study design and results for primary outcomes. J Periodontol, 2004, 75(8):1150 1160. https://doi.org/10.1902/jop.2004.75.8.1150 PMID: 15455745

[25] Fernandes JMA, Rego ROCC, Spolidorio LC, Marcantonio RAC Marcantonio Júnior E, Cirelli JA. Enamel matrix proteins associated with GTR and bioactive glass in the treatment of class III furcation in dogs. Braz Oral Res, 2005, 19(3):169175. https://doi.org/10.1590/s1806-83242005000300003 PMID: 16308603

[26] Palioto DB, Macedo GO, Queiroz AC, Taba M Jr, Souza SLS, Grisi MFM, Novaes AB Jr. Enamel matrix derivative and transforming growth factor-beta1 in Class III furcation defects. A histomorphometric study in dogs. J Int Acad Periodontol, 2012, 14(3):69-75. PMID: 22908536

[27] Peres MFS, Del Peloso Ribeiro E, Casarin RCV, Ruiz KGS Junior FHN, Sallum EA, Casati MZ. Hydroxyapatite/ $\beta$-tricalcium phosphate and enamel matrix derivative for treatment of proximal class II furcation defects: a randomized clinical trial. J Clin Periodontol, 2013, 40(3):252-259. https://doi.org/10.1111/jcpe. 12054 PMID: 23379539
[28] Chitsazi MT, Mostofi Zadeh Farahani R, Pourabbas M, Bahaeddin N. Efficacy of open flap debridement with and without enamel matrix derivatives in the treatment of mandibular degree II furcation involvement. Clin Oral Investig, 2007, 11(4): 385-389. https://doi.org/10.1007/s00784-007-0134-z PMID: 17623113

[29] Jaiswal R, Deo V. Evaluation of the effectiveness of ename matrix derivative, bone grafts, and membrane in the treatment of mandibular Class II furcation defects. Int J Periodontics Restorative Dent, 2013, 33(2):e58-e64. https://doi.org/10.11607/ prd.1428 PMID: 23484181

[30] Donos N, Glavind L, Karring T, Sculean A. Clinical evaluation of an enamel matrix derivative in the treatment of mandibular degree II furcation involvement: a 36-month case series. Int J Periodontics Restorative Dent, 2003, 23(5):507-512. PMID: 14620125

[31] Hoffmann T, Richter S, Meyle J, Gonzales JR, Heinz B Arjomand M, Sculean A, Reich E, Jepsen K, Jepsen S, Boedeker RH. A randomized clinical multicentre trial comparing enamel matrix derivative and membrane treatment of buccal class II furcation involvement in mandibular molars. Part III: Patient factors and treatment outcome. J Clin Periodontol, 2006, 33(8):575-583. https://doi.org/10.1111/j.1600-051X.2006. 00947.x PMID: 16899101

[32] Casarin RCV, Del Peloso Ribeiro E, Nociti FH Jr, Sallum AW, Sallum EA, Ambrosano GM, Casati MZ. A double-blind randomized clinical evaluation of enamel matrix derivative proteins for the treatment of proximal class-II furcation involvements. J Clin Periodontol, 2008, 35(5):429-437. https:// doi.org/10.1111/j.1600-051X.2008.01202.x PMID: 18341602

[33] Donos N, Glavind L, Karring T, Sculean A. Clinical evaluation of an enamel matrix derivative and a bioresorbable membrane in the treatment of degree III mandibular furcation involvement: a series of nine patients. Int J Periodontics Restorative Dent, 2004, 24(4):362-369. PMID: 15446406

[34] Aimetti M, Romano F, Pigella E, Piemontese M. Clinical evaluation of the effectiveness of enamel matrix proteins and autologous bone graft in the treatment of mandibular Class II furcation defects: a series of 11 patients. Int J Periodontics Restorative Dent, 2007, 27(5):441-447. PMID: 17990440

[35] Oliveira HFE, Verri F, Lemos CA, Cruz R, Batista VES, Pellizzer E, Santinoni C. Clinical evidence for treatment of Class II periodontal furcation defects. Systematic review and meta-analysis. J Int Acad Periodontol, 2020, 22(3):117-128. PMID: 32655037

[36] Sculean A, Windisch P, Döri F, Keglevich T, Molnár B, Gera I. Emdogain in regenerative periodontal therapy. A review of the literature. Fogorv Sz, 2007, 100(5):220-232, 211-219. PMID: 18078142

[37] Trombelli L, Farina R. Clinical outcomes with bioactive agents alone or in combination with grafting or guided tissue regeneration. J Clin Periodontol, 2008, 35(8 Suppl):117-135. https://doi.org/ 10.1111/j.1600-051X.2008.01265.x PMID: 18724846

[38] Shirakata Y, Miron RJ, Nakamura T, Sena K, Shinohara Y, Horai N, Bosshardt DD, Noguchi K, Sculean A. Effects of EMD liquid (Osteogain) on periodontal healing in class III furcation defects in monkeys. J Clin Periodontol, 2017, 44(3):298-307. https://doi.org/10.1111/jcpe.12663 PMID: 27978604

[39] Mardas N, Kraehenmann M, Dard M. Regenerative wound healing in acute degree III mandibular defects in dogs. Quintessence Int, 2012, 43(5):e48-e59. PMID: 22536596

[40] Heard RH, Mellonig JT. Regenerative materials: an overview. Alpha Omegan, 2000, 93(4):51-58. PMID: 11212411

\section{Corresponding authors}

Marina-Cristina Giurgiu, Lecturer, DMD, PhD, Department of Periodontology, Carol Davila University of Medicine and Pharmacy, 37 Dionisie Lupu Street, Sector 1, 020022 Bucharest, Romania; Phone +40728-174 219, e-mail: giurgiu.marina@yahoo.com

Ştefan-Dimitrie Albu, Assistant Professor, DMD, Department of Periodontology, Carol Davila University of Medicine and Pharmacy, 37 Dionisie Lupu Street, Sector 1, 020022 Bucharest, Romania; Phone +40749-249 999, e-mail: stevealbu@yahoo.com 